\title{
DEMOCRACY AT THE END OF HISTORY
}

\section{A DEMOCRACIA NO FIM DA HISTÓRIA}

\author{
VICENTE SANFÉLIX VIDARTE ${ }^{1}$
}

(Universidad de Valencia/Espanha)

\begin{abstract}
This article analyzes the loss of legitimacy that the economic crisis brought upon representative democracy and the consequences that can be drawn for the thesis of the end of History. The thesis we defend here is that the deterioration of the welfare state, as a result, under very specific conditions, of the capitalism in certain parts of the world, runs parallel with the delegative degradation of democracy.

Keywords: Democracy; capitalism; politics; history; Fukuyama.
\end{abstract}

If some postmodern theorists extended the death certificate of the great meta-narratives, and among them, that of the philosophy of history, ${ }^{2}$ with the fall of the Berlin Wall and the subsequent collapse of the socialist bloc, the thesis of the end of history ${ }^{3}$ gained greater significance.

Although both issues are related in a complex way - since obviously, it is not the same saying that the philosophy of history is no longer possible than to argue that it is not necessary because it has already been accomplished ${ }^{4}$ - which interest us here is only the second one. What we want to ask ourselves is, on the one hand, if the thesis of the end of history remains still defensible, immersed as we find ourselves in the first major crisis of global capitalism, and, on the other hand, what is the state of democracy at this juncture. ${ }^{5}$

Prima facie one might think that the outbreak of the crisis seems to challenge the thesis of the end of history inasmuch as it is an unforeseen and innovative event. ${ }^{6}$ But this appearance could be only a mirage, given that the thesis of the end of history does not so much imply the impossibility of the unexpected to occur but the impossibility for such events to question the hegemony of the market economy and of the political system of the liberal democracy that according to the supporters of this thesis corresponds to it; the question that will concerns us specially in this text. Hence, the defenders of the end of history were able to reconcile their theses about it, with the unleashing "events" such as economic crises of relevant Asian and South American countries, the emergence of Islamist terrorism, the wars in Kosovo, Iraq, Afghanistan, the 11 -s terrorist attack, etc...

Then, we could say that the occurrence of one or more "events" can be useful to demonstrate that history continues, but they do not question the thesis of the end of History (with capital H), with all that it entails. We are going to express, playing along with Fukuyama, that to question it, 
the occurrence of one or more "Events" (also capitalized) would be required. The problem, then, consists in deciding whether or not the current economic crisis is one of these "Events". ${ }^{7}$ Does the current economic crisis threaten the capitalism and - what concerns us especially - the liberal democracy?

When in 1999 Fukuyama wrote his text in defense of his thesis of the end of History, and therefore the validity of the liberal democracy, he pointed out something that may be of interest for us to start thinking about this issue. He said then: "... the events of the last ten years have discredited even more the main competitor (that is, of liberal democracy) ... the so-called "Asian development model". The economic crisis that hit Asia has shown the emptiness of Asian soft authoritarianism, because it intended to base its legitimacy on the economic progress, and that made it vulnerable in periods of crisis". ${ }^{8}$

Well, now that the crisis touches us to a much greater extent than to Asians countries, cannot we say the same about liberal democracy? Note that it is not about the economic crisis jeopardizing its survival - at the end of the day, the economic crisis of the late nineties did not end with the "soft" Asian authoritarianism either - but eroding its legitimacy. In fact, the existence of a shortage of legitimacy of the liberal political system is such an old and recurring theme as the very existence of such a system of government, which has triggered various proposals for its replacement or, more moderately, complementation: from the theories of participatory democracy, more or less inspired by the revolutionary practice of the workers' councils, ${ }^{9}$ to the latest of a radical or deliberative democracy. ${ }^{10}$

The novelty is that the crisis, and this seems hardly disputable, ${ }^{11}$ has provided that the mistrust towards liberal democracy transcends the more or less narrow circles of the intellectual elite to begin to spread through the increasingly large segments of the population who, let's put it graphically with Beck, begin to perceive that political institutions have become "horseless riders". ${ }^{2}$ Let us reflect briefly on how the reasons for this divorce would be of interest. In this article we will only point out the particularly significant, leaving the most obvious aside - but not least important; we refer, of course, to the high level of corruption of the political class in some countries, including ours.

The first one we want to point out is strictly political. A symptom of the discredit that threats the liberal democracy could be inferred from the fact that the way it operates, in the critical juncture we find ourselves, allows us to describe it in Carl Schmitt's terms; that is, in terms of one of its greatest critics.

Indeed, the crisis has made the different governments of the nations that suffer from it face similar situations that Carl Schmitt regarded as exceptional, and when confronting them they have acted as the German jurist and philosopher prescribed, namely: making sovereign decisions that on 
the one hand, do not in the least take into account, when not squarely contradict, the electoral programs for which those governments were elected; and on the other hand, their settlement in the existing legal order become, in many times, to say the least, problematic, when not constituting a plain and simple peremptory modification of this same order. ${ }^{13}$ Thus, the liberal democracy of the countries in crisis is increasingly acquiring a delegative tinge, to mention a term that has been coined by the Argentinean political expert Guillermo O'Donnell, ${ }^{14}$ and becoming increasingly less representative. The result is easily understandable also in schmittians terms: since in liberal democratic systems the legitimacy depends crucially on the representative nature of the governments and respect for legality, this legitimacy cannot but deteriorate with the loss or/and violation of both of them.

However, and this may seem paradoxical, hoarding, if not usurpation of sovereignty by governments of nations in crisis, does not prevent the population from having increasing doubts about the government's effective ability to make decisions. This is due to a general reason that becomes even more acute in the case of countries that belong to the European Union and especially in those that adopted the single currency, namely that this exceptional situation that they have to face presents traits of clear global ${ }^{15}$ issues or, at least, it goes beyond the national boundaries as far as the power of governments reach. Then, you might get the impression, that indeed seems quite justified, that the elected institutions lack effective decision-making capacity, while the capable institutions - IMF, World Bank, ECB, the European Commission, etc. - are not elected, or at least not directly, by anyone. In any case, all redounds in a deficit of representation and, therefore, legitimacy, of the political institutions of the liberal democracies subject to the crisis.

If what we have just noted here, deserves special attention to explain the erosion of legitimacy of the liberal democracy caused by the crisis, much more importance should be given to the point that we want to highlight now of nature less strictly political than socio-economic.

It seems hardly debatable when analyzing the social history of the late twentieth ${ }^{16}$ century, that the legitimacy of the liberal democratic forms of government came from the hand of a capitallabor pact that allowed the gradual increase in the purchasing power of wage income, especially in Europe, building a welfare state that guaranteed education, health care and a decent retirement for its citizens; conditions that allowed in these societies the emergence of a large middle class that, along with other factors such as the increasing dominance of the tertiary sector to the detriment of the primary and secondary, or in other words: the conversion of the most advanced industrial societies into societies of services, made the class struggle temper, in such a way ${ }^{17}$ that their political stability developed into what we have recently encounter.

However, from the last quarter of the last century a series of events (or Events?) that have led to question this statu quo have occurred (or have Occurred?). Find here a non-exhaustive list: 
the violent neoliberal policy offensive to reduce the role of the state, ${ }^{18}$ the deregulation of the financial markets, ${ }^{19}$ the development of new information technologies and communication, that have put on the agenda the mobility, not to say flight, of capitals, the collapse of the socialist bloc, ${ }^{20}$ the rise of "Communist" China as a world economic power ... or, the last but not the least, the current crisis.

Indeed, in those countries hit by the crisis, their governments have finally adopted - leaving the value judgments about their good or bad attitude in doing so aside - an austerity policy which objectives are to reduce the state deficit and to increase the competitiveness of their economies; and to achieve both objectives, they recurred to cuts in social benefits in education, health, pensions, etc, and to the proposal to adopt a series of labor reforms which immediate consequence is no other than the lowering of labor costs (a labor costs decrease that the state has achieved by imposing its employees more and more salary cuts).

That means that the dual socio-economic condition, material foundation of the stability and legitimacy that the liberal-democratic political regime had been gaining since the end of World War II: the increase in the purchasing power in wage income and the development of a social protection system, have entered into outright recession. Instead, the percentage of population that crosses the dark poverty threshold increases, the one-time middle class depletes and the trend that was already occurring before the crisis radicalizes leading to an increase of economic inequality. ${ }^{21}$ The capitallabor pact that allowed the development of welfare societies seems broken. We have entered a zerosum game and there seems to be no doubt of who wins and who losses it. Once the deregulation of the financial market, the offshoring and the almost entirely free capital flow succeed, it uses the crisis to assault the last trenches left to be conquered: the deregulation of the labor market and the dismantling of social benefits, leaving the way open to turn them into fertile fields where new and lucrative business flourish.

All these considerations allow us to understand the reason behind those who blew the whistle on the "cultural" drifting of the Left. ${ }^{22}$ No matter how understandable it was during the economic boom, it seems now that there are urgent demands more important than defending the right to claim recognition of difference. The problem is that the traditional Left does not seem better equipped to deal with what is happening to the postmodern and basically academic Left. Its long collusion with the discredited system makes it also fall into discredit. And the same changes that have led us to the capitalism in its current global form which have narrow, as we have seen, the maneuver margin of national governments, affect although not to a lesser extent, the old Left organizations. Certainly, the number of dispossessed increases, but this does not endow them with the uniformity nor the discipline that was premised on the Marxist concept of class, touchstone, after all, of all those organizations, whether these claimed to be revolutionary or reformist, socialist, 
communist or libertarian.

Neither trade unions nor the traditional left-wing parties can expect the return of a homogeneous working class in its composition and vindications. Fragmentation also remains, if not increases, among those who are paying for the crisis. It is not the same being a bankrupt selfemployed than an company employee who has been fired; an emigrant than a national; a civil servant than a private employee; a worker in SMEs than a worker in a macro-enterprise; evicted for not paying the mortgage than for not paying the rent; a young recently unemployed than a longterm unemployed adult ... governments know that this fragmentation favors their freedom of action and promote it conscientiously. ${ }^{23}$

But even if all this heterogeneous mixture became a strong homogeneous mass, the most decisive barrier would still remain to be overcome. Resistance, presumably, would be against the respective governments ... governments that, as we saw before, are already doubtful to have the capability to decide which policies to apply. But, actually, is it still imaginable the setting up of international solidarity even if restricted to the European Union scope? Is it conceivable that the German, French, British unions call the strike, to demonstrate in solidarity with the Spanish workers? Did Spaniards unions and left-wing political parties appeal to solidarity with the Greek, Portuguese or Irish employees, predecessors of our present misery?

In short, perhaps the diagnosis / regret that the Left is absent - diagnosis / regret nothing less than of Fukuyama ${ }^{24}$ himself! - could be a little exaggerated; what does not seem as exaggerated is that, for no superficial reasons that have to do, ultimately, with the occurrence of profound social changes in the last thirty years, this crisis caught the Left, say the least, on the wrong foot.

Perhaps it is now time to outline some recap and conclusions, however provisional, on the issue that concerns us. Of course, the crisis does not seem to be the "Event" that will topple the hegemony of the liberal democracy. To this date there appears to be no available and desirable alternative to it - although this does not mean that we do not have to be aware of authoritarian involutions that the crisis, like $11 \mathrm{~s}$ attack at the time, may be producing. Yet, the crisis can draw conclusions in the field of political philosophy. If we are not mistaken in our diagnosis, the crises becomes a particularly significant link in a chain of events triggered in the past three decades which consequence seems to point in the one and the same direction: the deterioration, if not its delegative denaturation, of the legitimacy of this form of government. ${ }^{25}$

But this conclusion - more realistic, we believe, than moderated - in the field of political philosophy is enough, in our opinion, to seriously question the thesis of the end of History because, as we clarified before, it is not required that the liberal democracy disappears de facto to falsify it, only that its legitimacy is sufficiently eroded (not to mention that it denatures in more or less delegative forms). And this is, in our view, what is happening. Perhaps none of the mentioned 
events - deregulation of financial markets, neoliberal political-ideological offensive, the emergence of capitalism in its informational version ... ultimately, the outbreak of the crisis - may in isolation constitute the "Event" that reactivates History. But the sum of them all, following our thesis, has already reactivated it. In this regard, it is not without significance that Fukuyama himself has shifted to talk about the "Future of History" 26 and he foresees that the main dangers threatening the happy ending he had envisioned are precisely the Chinese model of authoritarian capitalism and, overall and particularly, the rapid decline of the middle class in democratic countries affected by the crisis. $^{27}$ And what happens is that the term "democracy", when deprived of its socio- economic sustenance, is in danger of becoming almost as vacuous as the adjective "communist" when applied to the current Chinese system.

We cannot, however, leave at this point the analysis of the thesis of the end of history, because even assuming that we have successfully shown the weakness of one of the basis on which it relied on - its political support: the unquestionable legitimacy of liberal democracy - we still have to analyze its other ground: the unsurpassable capitalism as mode of production. And, after all, it is possible that both are intrinsic and deeply interconnected.

In fact, our conclusion here should not please the leftist spirits, quite the opposite, i.e.: it should fill them with concern. Then, what we have argued here - and we believe that Fukuyama himself has become aware of ${ }^{28}$ - can be summarized as follows: the Event that brings into question the legitimacy of liberal democracy is not a revolutionary Event but, basically, ${ }^{29}$ the sum of events that crystallize in the emergence of a new type of capitalism (or, if preferred, a new phase of capitalism): post-industrial capitalism, global, informational, or as you prefer to call it (we would suggest to call it "oriental" due to reasons to be seen immediately). A particularly predatory capitalism, a capitalism of scorched earth (and this expression should often be taken literally), in which to achieve the sole purpose really persecuted - not the profit but the continuous growth of its rate $^{30}$ - by any means may seem allowed - from the exemption from the tobacco law to labor market exclusion of employees who dare to organize. Capitalism, in short, that threatens to reverse the geoeconomic sense that was expanding until now, shifting from the Westernization of the East ${ }^{31}$ to the threat of the Easternization of the West, i.e.: a more intensive exploitation of the workforce with much lower ${ }^{32}$ individual and, above all, social wages.

If liberal democracy threatens to be nothing but an empty shell; capitalism, in contrast, has acquired, in its new version, despite the crisis, or just thanks to it, an up to now unknown strength. And as far as we know, we can now say that this crisis is not the Event of revolutionary consequences call to bring to end the capitalist mode of production. In fact, our diagnosis, let us say it now, is that the crisis will come to punish the resetting of the power that had been happening within it. ${ }^{33}$ A new distribution of power in which the room that needs to be necessarily made for the 
emerging economic powers - with China on the leading role - must be released by those countries that have been most severely affected by this crisis. ${ }^{34}$

We can now reach a conclusion with which finalize this writing. The thesis of the end of History claimed that liberal democracy and the capitalist mode of production were the unsurpassable political and economic horizons for humanity. What the current economic crisis, as far as we understand, reveals is that the global development of capitalism erodes seriously the legitimacy of democracy. The underlying problem, ultimately, is that the assumption behind the optimistic thesis of the end of History, which is the correspondence between liberal democracy and capitalism, does not seem sustainable. The economy rules over politics imposing its logic. The challenge is that politics manage to bridle the economy. A challenge in which not only the future of liberal democracy but also of democracy tout court is at stake. 


\section{Notes:}

${ }^{1}$ Professor at the Universidad de Valencia, Valencia, Spain.

${ }^{2}$ Obviously, we are referring to the work of F. Lyotard, The Post-modern Condition. A Report on Knowledge. Minneapolis, University of Minnesota Press, 1984. The complaint of the philosophy of history that Lyotard and other postmodern authors did was, in short, nothing but denouncing a narrative of history influenced by the teleological premise of progress. The crypto-theological character of the philosophy of history, seen in this light, had already been criticized by Walter Benjamin in the first of his Theses on the Philosophy of History. Cf. W. Benjamin, Essays and Reflections. New York, Schocken Books, 1968.There is a Spanish version freely available on the web: http://www.elabedul.net/Documentos/Tesis.pdf.

${ }^{3}$ The inevitable reference in this case is F. Fukuyama, The End of History and the Last Man. New York, Avon books, 1992. This famous book was, in fact, the development of the ideas contained in a 1989 article, more cautiously entitled, "The End of History?" published in the journal The National Interest. A Spanish version of this article, along with other texts of Fukuyama and other authors that discuss their thesis, is freely available in: http://firgoa.usc.es/drupal/files/Francis\%20Fukuyama\%20\%20Fin\%20de\%20la\%20historia\%20y\%20otros\%20escritos. pdf.

${ }^{4}$ On the other hand, neither of them must be confused with the philosophical discussion, mainly of epistemological nature, about the status of history as a discipline: the discussion about the status of historia rerum gestarum as opposed to the discussion about the meaning of res gestae which is what ultimately is at stake in the debate about the end of (the philosophy of) history. Perhaps, in order to avoid misunderstandings, it would be convenient to preserve the label of "historiography" for historia rerum gestarum. For a critic on the points of view of Popper - and positivist - about the same, Cf. Sanfélix, V. "Anti-antihistoricismo". Contrastando a Popper. Ed . A. J. Perona. Madrid: Biblioteca Nueva, 2008 .

${ }^{5}$ Thus, we disregard the issue about whether the philosophy of history is still being possible and even desirable as, for example, Antonio Campillo seems to think. Campillo has smartly traced the genealogy of the philosophy of classical history while he vigorously argued for the need of a new one. Cf. "La invención de la historia universal" and "Hacer lo (im)posible", chapters 2 and 4, respectively of El concepto de lo politico en la sociedad global. Barcelona: Herder, 2008 .

${ }^{6}$ The category of "event" plays a central role in the theories of certain intellectual left. This is the case of, for example, Negri, Antonio and Hardt, M. Empire. Cambridge: Polity Press, 2002.

7 "At first glance seems absurd and insulting for the memory of those who died on September 11, to declare that this unprecedented attack does not reach the level of historical event. But the way I used the word history, or preferably, History was different: I referred to the progress of mankind throughout the centuries toward modernity, characterized by institutions such as the liberal democracy and the capitalism." "We are still at the end of history". Freely available in www.militaryphotos.net/forums/showthread.php?22366-We-re-still-at-the-end-of-history. Page 23.

8 "Thinking about the end of history ten years later." Idem. Page 21.

${ }^{9}$ Consider the cases of Hannah Arendt, The Human Condition. Cambridge: Polity Press, 1993 or Guy Debord, Society of the Spectacle. New York, Zone Books, 1994.

${ }^{10}$ Which main references are certainly Chantal Mouffe, The Return of the Political. Cambridge: Polity Press, 1999 and Jürgen Habermas, Between Facts and Norms. Cambridge. Polity Press. 1996, respectively. Cf. for an overview of the case, David Held, Models of Democracy. Cambridge. Polity Press, 2006. Also, for a synoptic view, while clear and concise business, Jesica Baños' article, “Teorías de la democracia: debates actuales". Andamios, Vol. 2, № 4, 2006.

${ }^{11}$ At least in my country. We only need to consider that according to the surveys by the Centre of Sociological Research, politicians are now the third most serious problem, just behind unemployment and economic problems.

${ }^{12}$ Cf. U. Beck, Democracy whithout enemies. Cambridge, Polity Press. 1998.

${ }^{13}$ Let us recall the express constitutional reform agreed by the Spanish Socialist Worker Party - the supposed Left - and the Popular Party - the Right. We especially refer to Carl Schmitt's first work on political theology, gathered in C. 
Schmitt, Political Theology. Cambridge (Mass), MIT Press. 1985

${ }^{14}$ Cf.G.O'Donnell. "Delegative Democracy?" $\quad$ Text $\quad$ freely http://kellogg.nd.edu/publications/workingpapers/WPS/172.pdf.

15 What highlights something that has been repeatedly mentioned since the advent of the global society: the obsolescence of the nation-state model to face the challenges that it entails.

${ }^{16}$ Antonio Campillo offers a quick and condensed analysis of this period in his essay "Del estado soberano a la globalización del riesgo", collected in his book, cited above, El concepto de lo politico en la sociedad global. Cf. p. 231 et seq. What we are going to say about it, fully agrees with his exposure.

${ }^{17}$ To the point that many of those who wanted to keep seeing something similar to the persistence of the old social structure of the industrial capitalism itself, chose to stop talking about "social classes" to start talking about "stratus". The blurring of social classes is reflected in the variable identification that the intellectual Left has been doing of the revolutionary subject (or at least non-conformist): from Foucault's "The Plebe" to the Negri and Hardt's "The Multitude" , through "el pueblo" of our dear Agustín García Calvo. Cf. M. Hardt \& A. Negri, Multitude. New York, Penguin, 2004; A. García Calvo, Contra la paz. Contra la democracia. Barcelona, Virus,1993. M. Foucault, Dits et écrits III. Paris, Gallimard, 1994. On the latter, for these and other related issues, is worth reading J.L. Moreno Pestaña, Foucault y la política. Cienpozuelos (Madrid), Tierradenadie, 2011.

${ }^{18}$ Policy that found on Baroness Margaret Thatcher and comedian Ronald Reagan, turned into a politician, its first apostles.

${ }^{19}$ Which first steps, as Krugman reminded us, had already been released by the Democratic administration of Jimmy Carter. See Cf. P. Krugman, ;End this Depression Now! New York, W.W. Norton \& Company, 2012.

${ }^{20}$ The tough old Stéphane Hessel speaks of the terrible fear of a Bolshevik revolution that seized the owners, making it responsible for its collusion with fascism. Cf. Time for Outrage Quartet Books, Limited, 2011. But that same fear had a beneficial influence on Europe in the post-war. Antonio Campillo clearly formulated the thesis that we undersign, "... the climate of Cold War and the fear of the Soviet Union contributed to the owning class of the capitalist West should do major concessions to the labor movement." Op.cit. Page 232. He is not, by the way, the only one who has noticed this connection.

${ }^{21}$ Note some data. According to the UNICEF report "Childhood in Spain 2012-2013. The impact of the crisis on children", $26 \%$ of children in our country, about two million two hundred thousand children, live in relative poverty (the $21^{\prime} 8$ of the total population is already below the threshold of poverty); according to the latest report from the CYD foundation the number of unemployed persons between 25 to 64 years old with a higher degree - middle classes support - had increased by 2.86 in Spain in late 2011 in comparison with the last quarter of 2007; and as per Eurostat reports, in 2009 domestic inequality in Spain grew until it became the fourth country in the European Union where it is more acute.

${ }^{22}$ Zizek or Rorty, for example. In this regard, we refer to Francisco Martorell, "Cuando las partes devoran al todo: crítica al giro postmoderno de la emancipación a propósito de Rorty y Zizek”. Astrolabio. Revista internacional de filosofía. Año 2011, No 1, Págs 302-316. http://www.raco.cat/index.php/Astrolabio/article/view/239033/321305.

${ }^{23}$ For instance, the way in which unemployment benefit is distributed.

24 "The Future of History. Can Liberal Democracy Survive the Decline of the Middle Class?" Port Vitoria, 5 Jan. 2012. You can find a Spanish version on the net. For example, in http://www.penultimosdias.com/2011/12/30/el-futuro-de-lahistoria/. The title of the letter, on the other hand, makes it clear that we will return to it immediately. Although we may disagree with his idealistic explanation of the faults attributed to the Left, the same criticisms are not trivial.

${ }^{25}$ This conclusion would be unilateral if we did not even mention another political phenomenon of opposite meaning. We refer to the emergence of movements of outraged citizens as $15 \mathrm{M}$ in our country or the Occupy Wall Street in USA. The theoretical significance thereof is, in our view, clear. They constitute an amendment to the realization of liberal democracy from the vindication, and above all, practice of the participatory and radical aspects of itself. Although, as demonstrated dramatically in our country, they did not have a significant electoral impact, we do not think its influence must be underestimated. To begin with, they, not the traditional leftist organizations, are the ones who have managed to articulate the closest movement to a significant transnational defense response to the consequences of the crisis. To continue, they have succeeded in imposing many of their claims on the agendas of the political parties (if only for them 
to reject them). Finally, they have undeniably contributed to the discredit of the political class who has appropriated the springs of liberal democracy threatening to empty it of content. In addition, they have also contributed to the crisis of legitimacy of the current political system.

${ }^{26}$ We now, as promised in a previous footnote, return to Fukuyama's article about "The Future of History".

${ }^{27}$ Some data and considerations contributed by Fukuyama about the United States are no less significant than those we've seen related to my country: "Finally, the economist Raghuram Rajan has argued persuasively that since Americans are reluctant to commit to a clear redistribution, the United States has sought instead a very dangerous and inefficient form of redistribution over the past generation, subsidizing mortgages for low-income family homes. This trend, facilitated by a glut of liquidity coming from China and other countries, gave many ordinary Americans the illusion that their living standards were rising steadily over the past decade. In this regard, the burst of the housing bubble of 2008-2009 was not but a cruel reversal of meaning. Americans today can enjoy cheap mobile phones, no expensive clothes and Facebook, but increasingly they cannot afford their own homes, or health insurance, or a comfortable pension at retirement.

An even more worrying phenomenon, identified by the venture capitalist Peter Thiel and economist Tyler Cowen, is that the benefits of the most recent wave of technological innovation has grown disproportionately for the most talented members of society and education. This phenomenon helped cause the massive growth of inequality in the United States over the past generation. In 1974, one percent of the richest families took home nine percent of GDP; in 2007, that share had risen up to $23.5 \%$ ". "The Future of History. Can Liberal Democracy Survive the Decline of the Middle Class?”. Freely available in www.foreignaffairs.com/articles/136782/francis-fukuyama/the-future-of-history.

${ }^{28}$ It, by the way, would demonstrate that he was never a simple neo-liberal, at the same time that he could explain his slow but steady distancing of theses more characteristic of the American Neocons.

${ }^{29}$ Basically does not mean only. We have already said what we think of the contribution that the protest movements against the crisis have made to this process. But note that, as its description shows, these have had a reactive nature. That is, they have acted, or at least have acted in a massively significant way, post hoc only, where hoc refers to the economic crisis.

${ }^{30}$ As Luis Arenas has timely reminded us in his writing, still unprecedented, "Es el capital, estúpidos!". Furthermore, obviously this aim is not presented in this way to the plebe, crowd or people but rather as to create jobs.

31 "The bourgeoisie subjected ... East to West", had already written Marx and Engels in Manifesto of the Communist Party.

${ }^{32}$ A possibility, of course, that did not go unnoticed to Marx, who foreseeing that the, as we would call it today, global development of the capitalist market lead to a cosmopolitan competition among the workers, concludes: “...today, thanks to the competition on the world-market... we have advanced much further. 'If China', says Mr Stapleton, M.P., to his constituents, 'should become a great manufacturing country, I do not see how the manufacturing population of Europe could sustain the contest without descending to the level of their competitors'... The wished-for goal of English capital is no longer Continental wages but Chinese" Capital. Vol. I, Chapter 24. Note 40. At this point is where, in our view, Fukuyama was totally wrong. China's threat to Western countries is not political - to argue that nobody in the West wants to adopt the Chinese "communism" as a model of political regime is so obvious that does not even deserve consideration - but economic. It is his version of capitalism which conceals the trend that attracts the market forces.

${ }^{33}$ In fact, to get back on the subject of the middle classes, we must say that these do not decrease to a global scale but increases. And while they undergo a tough slimming diet in old Europe or the United States, they vigorously grow in the emerging countries. Cf. article by A. Ortega, "El declive de las clases medias", published in El País, edition of July 1, 2012. Something else, given the ambiguity of the term "middle class", is whether these new middle classes have the same characteristics as the European-American.

${ }^{34}$ Like my country. Does anyone remember the ambitions of Aznar about Spain entering in the select group of the G8? Today Rajoy hardly receives an invitation to participate in the G 20 meetings. 


\section{References:}

Arendt, Hannah. The Human Condition. Cambridge: Polity Press, 1993.

Baños, Jesica. “Teorías de la democracia: debates actuales”. Andamios, 4 (2006): Pages 35-58

Beck, Ulrich. Democracy whithout enemies. Cambridge, Polity Press. 1998.

Benjamin, Walter. Essays and Reflections. New York, Schocken Books, 1968.

Campillo, Antonio. El concepto de lo politico en la sociedad global. Barcelona: Herder, 2008.

Debord, Guy. Society of the Spectacle. New York, Zone Books, 1994.

Foucault, M. Dits et écrits III. Paris, Gallimard, 1994.

Fukuyama, Francis. The End of History and the Last Man. New York, Avon books, 1992.

Fukuyama, Francis. "The future of History. Can Liberal Democracy survive the decline of the Middle Class?”. Foreign Affairs. Vol. 91. N. 1. Pages 53-62

García Calvo, A. Contra la paz. Contra la democracia. Barcelona, Virus, 1993.

Habermas, Jürgen. Between Facts and Norms. Cambridge. Polity Press. 1996,

Hardt, M. and Negri, A. Multitude. New York, Penguin, 2004.

Held, David. Models of Democracy. Cambridge. Polity Press, 2006.

Hessel, Stéphane. Time for Outrage! Quartet Books, Limited, 2011.

Krugman, Paul. End this Depression Now! New York, W.W. Norton \& Company, 2012.

Lyotard, Jean-François. The Post-modern Condition. A Report on Knowledge. Minneapolis, University of Minnesota Press, 1984.

Martorell, Francisco. "Cuando las partes devoran al todo: crítica al giro postmoderno de la emancipación a propósito de Rorty y Zizek". Astrolabio. Revista internacional de filosofía. 01 (2011): 302-16. Accessed in 2013. http://www.raco.cat/index.php/Astrolabio/article/view/239033/321305.

Moreno Pestaña, J.L. Foucault y la política. Cienpozuelos (Madrid), Tierradenadie, 2011.

Mouffe, Chantal. The Return of the Political. Cambridge: Polity Press, 1999

Negri, Antonio., and Hardt, M. Empire. Cambridge, MA: Harvard University. Press, 2000.

O'Donnell, Guillermo. "Delegative Democracy?" Accessed in December 10, 2013. http://kellogg.nd.edu/publications/workingpapers/WPS/172.pdf

Ortega, Andrés. "El declive de las clases medias,” El País, July 1, 2012, accessed in December 10, 
2013, http://sociedad.elpais.com/sociedad/2012/07/01/actualidad/1341168597_563026.html.

Sanfélix, Vicente. "Anti-antihistoricismo". In Contrastando a Popper. Edited by A. J. Perona. Madrid: Biblioteca Nueva, 2008. Pages 87-124 